\title{
Uses of old long-stay hospital buildings
}

\author{
Ana Lowin, Martin Knapp and Jennifer Beecham
}

The enormous resource pressures on mental health care, both hospital- and communitybased, have recently been re-affirmed (Johnson et al, 1997: Shepherd et al, 1997). There are many acute units operating at occupancy levels greater than $100 \%$, while adequately staffed community accommodation remains scarce in some localities. Many seriously mentally ill people living independently cannot get access to day support and other services they need (Audit Commission, 1994). Closing the old psychiatric and learning disability hospitals was promoted in the interests of patients' quality of life and normalisation (Leff et al, 1996). However, it is also hoped that re-using (or selling) the sites can help the development of a span of good mental health services in the community, which could ease the pressure on acute hospital beds.

Most of England's long-stay hospitals were built in the latter part of the 19th and beginning of the 20th century. The Victorians spent a fortune on building and landscaping their asylums. Formerly the main treatment base for seriously ill psychiatric and learning disability patients, these institutions have been closing since the 1960s. Replacement community services must be built before resources can be released from the long-stay hospitals. The white paper 'Caring for People' in 1989 proposed agreements with developers to build new places in exchange for the sites. This and the provision of bridging finance has proved insufficient in the majority of cases. Commonly the authorities' pragmatic best is to aim for the fastest sale possible. It has often been suggested that many sites sit vacant for long periods, but there are no centralised records on site sale or reuse (Groves, 1993). So what has happened to the old hospitals?

We identified the 206 large psychiatric and learning disability hospitals with over 100 beds in 1962 and 1986 respectively. In August 1996 National Health Service (NHS) regional executives were sent questionnaires, one per site, asking for summary information on closure dates, current use of hospital sites and difficulties relating to the sale of sites. We received 74 returns and, where missing, used information from the most detailed alternative source (reports by Save Britain's Heritage (Binney, 1995), the Mental Health Task Force (Davidge et al, 1993), or correspondence with local people involved with hospital run-down and site sale).

The planning permission category for a longterm hospital is 'institutional use', that is it may be used for a hospital, school, army base etc. The value of the site will increase dramatically if planning permission is obtained for other uses. For example, in the Mersey region a value of around $£ 50000$ per acre is likely for land with institutional planning permission and $\$ 250000$ per acre for land with planning permission for housing. Unfortunately, obtaining planning permission for the sites is a lengthy and sometimes impossible process. Public opposition to site development is often fierce. Further, many buildings are listed or have conservation orders on them, and sites are often on green belt land. This can mean that the original buildings must be reused, not demolished, and that the density of redevelopment cannot exceed the original footprints, creating difficulty in finding appropriate buyers.

We found that half of the land on sites no longer in original use was vacant (Table 1 ). Planned uses, regularly mentioned for this land, were mainly for residential development. although business, leisure and retail plans were also often mentioned. Of the 40 sites in which hospitals had closed $40 \%$ remained predominantly (at least 90\%) vacant. On these sites. vacant for up to 16 years, hospitals closed an average of four years ago. Reused land was most commonly deployed for agricultural, residential. education, leisure, business and other NHS activities. Land was reused by the NHS for a variety of purposes, including provision of hospital services, nurse's accommodation, day centres and administration. Agriculture and NHS activities were found to be more common on sites with part or all of the original hospital open, and did not feature in plans for vacant land. As it is relatively straightforward to convert land for these purposes it seems that these may well be short-term uses while planning permission is sought. 
Table 1. Reuse of land on the sites of England's old asylums

\begin{tabular}{lcc}
\hline & $\begin{array}{l}\text { Percentage reuse } \\
\text { of land, excluding } \\
\text { portions of } \\
\text { sites remaining } \\
\text { in original }\end{array}$ & $\begin{array}{l}\text { Percentage reuse } \\
\text { of land on sites } \\
\text { with closed } \\
\text { hospltals }(\boldsymbol{n}=40)\end{array}$ \\
use & use $(\boldsymbol{n}=75)$ & 52 \\
categories & 49 & 19 \\
\hline Vacant & 25 & 12 \\
Agriculture & 11 & 10 \\
Residential & 7 & 3 \\
Education & 3 & 1 \\
Leisure & 3 & 3 \\
NHS use & 2 & $<1$ \\
Business & $<1$ & \\
Retail & &
\end{tabular}

Once deliberately remote, the former asylums now often occupy prime sites with attractively architectured buildings and grounds. Many of the old asylums (which often sheltered up to 3000 patients) are set within sites of 80 acres or more where chapels, orchards and farms were once housed. These spacious sites are often in excellent locations on high ground, with fine views, on the edge of (or now sometimes surrounded by) towns and cities. This picture might encourage one to imagine that the demand and value for these sites would be enormous.

Our survey indicates that $40 \%$ of the sites remain vacant. Each vacant site generates maintenance costs $(£ 10000-336000$ per year were quoted for 10 sites by one regional finance office), but these pale in comparison to the likely opportunity costs measured in terms of the health and community care services that could be provided with the resources released by selling or reusing vacant sites.

The scale of these opportunity costs depends on site values, sums that ultimately depend on location and planning permission. If the land cannot be sold at a reasonable price, should some of the cost-effectiveness arguments back- ing decisions for de-institutionalisation be called into question?

In 1994 the Government recommended that sales money be ring-fenced for adult mental health (Department of Health, 1994). This probably has not happened, but delays in selling hospital sites are exacerbating an already difficult resource problem. If the future development of community mental health care is even partly dependent on the release of resources from asylum sites, we could be in for a long wait.

\section{References}

Audrt Commission (1994) Finding a Place: A Review of Mental Health Services for Adults. London: HMSO.

BinNEY, M. (1995) Mind over matter. A study on the country's threatened mental asylums. London: Save Britain's Heritage.

DAvide, M., EuAs, S., Jayes, B., et al (1993) Survey of English Mental Illness Hospitals, Report prepared for the Mental Health Task Force. Birmingham: Health Services Management Centre, University of Birmingham.

Department OF HEALTH (1994) Government Response to the First Report of the Health Committee. Better off in the Community? The Care of People who are Seriously Mentally IU? London: HMSO.

Groves. T. (1993) Government lacks data on mental hospital closures. British Medical Journal, 306, 475476.

JOHNSON, S., RAMSEY, R., THORNICROFT, G., et al (1997) London's Mental Health. Report to the King's Fund London Commission. London: King's Fund.

Leff. J., TRIEMAN, N. \& GROOCH, C. (1996) Team for the Assessment of Psychiatric Services (TAPS) Project 33: Prospective follow-up study of long-stay patients discharged from two psychiatric hospitals. American Joumal of Psychiatry. 183. 1318-1324.

SHEPHERD G., BEARDSMOORE, A., MOORE, C., et al (1997) Relation between bed use, social deprivation, and overall bed availability in acute adult psychiatric units, and alternative residential options: a cross sectional survey, one day census data, and staff interviews. British Medical Journal, 314, 262-266.

Ana Lowin, Martin Knapp and Jennifer Beecham. Centre for the Economics of Mental Health, Institute of Psychiatry, London SE5 8BB 